\title{
Exploring how educators at the workplace inform their judgement of students' professional performance
}

Citation for published version (APA):

De Vos, M. E., Baartman, L. K. J., Van der Vleuten, C. P. M., \& De Bruijn, E. (2019). Exploring how educators at the workplace inform their judgement of students' professional performance. Journal of Education and Work, 32(8), 693-706. https://doi.org/10.1080/13639080.2019.1696953

Document status and date:

Published: 01/01/2019

DOI:

10.1080/13639080.2019.1696953

Document Version:

Publisher's PDF, also known as Version of record

Document license:

Taverne

Please check the document version of this publication:

- A submitted manuscript is the version of the article upon submission and before peer-review. There can be important differences between the submitted version and the official published version of record.

People interested in the research are advised to contact the author for the final version of the publication, or visit the DOI to the publisher's website.

- The final author version and the galley proof are versions of the publication after peer review.

- The final published version features the final layout of the paper including the volume, issue and page numbers.

Link to publication

\footnotetext{
General rights rights.

- You may freely distribute the URL identifying the publication in the public portal. please follow below link for the End User Agreement:

www.umlib.nl/taverne-license

Take down policy

If you believe that this document breaches copyright please contact us at:

repository@maastrichtuniversity.nl

providing details and we will investigate your claim.
}

Copyright and moral rights for the publications made accessible in the public portal are retained by the authors and/or other copyright owners and it is a condition of accessing publications that users recognise and abide by the legal requirements associated with these

- Users may download and print one copy of any publication from the public portal for the purpose of private study or research.

- You may not further distribute the material or use it for any profit-making activity or commercial gain

If the publication is distributed under the terms of Article $25 \mathrm{fa}$ of the Dutch Copyright Act, indicated by the "Taverne" license above, 


\title{
Journal of Education and Work
}

\section{Exploring how educators at the workplace inform their judgement of students' professional performance}

\author{
M. E. De Vos, L. K. J. Baartman, C. P. M. Van Der Vleuten \& E. De Bruijn
}

To cite this article: M. E. De Vos, L. K. J. Baartman, C. P. M. Van Der Vleuten \& E. De Bruijn (2019) Exploring how educators at the workplace inform their judgement of students' professional performance, Journal of Education and Work, 32:8, 693-706, DOI: $10.1080 / 13639080.2019 .1696953$

To link to this article: https://doi.org/10.1080/13639080.2019.1696953

Published online: 29 Nov 2019.

Submit your article to this journal $\longleftarrow$

ЏII Article views: 300

Q View related articles $₫$

View Crossmark data

Citing articles: 2 View citing articles 주 


\title{
Exploring how educators at the workplace inform their judgement of students' professional performance
}

\author{
M. E. De Vos $\mathbb{D}^{\mathrm{a}, \mathrm{b}}$, L. K. J. Baartman ${ }^{\mathrm{a}, \mathrm{b}}$, C. P. M. Van Der Vleuten $\mathbb{D}^{c}$ and E. De Bruijn (iD)
}

aResearch Group Vocational Education, Utrecht University of Applied Sciences, Utrecht, The Netherlands; ${ }^{b}$ Welten Institute, Open University of the Netherlands, Heerlen, The Netherlands; 'Department of Education Development and Research, Maastricht University, Maastricht, The Netherlands

\begin{abstract}
Vocational education aims at preparing students for their future as professionals; thus, students are often required to undergo a form of on-the-job learning. Assessment of professional performance during on-the-job learning is not based on single observations, but on prolonged participation at the workplace culminating in judgement by a workplace educator. However, little is known about how educators reach a judgement. This paper, therefore, aims at exploring how educators inform their judgements about students' professional performance. We consider the workplace to be a participatory learning environment, which entails that judgement about professional performance should be made in relation to the community students participated in and that the educator from that community has a central role. Our study takes an explorative approach based on interviews and uses template analysis to generate insight. Findings revealed that educators use multiple strategies to gather and process information about students to inform their judgement. Findings also showed that assessment starts at the first meeting, when the educator forms a first impression of the student and judges whether or not the student is suitable for the job. Educators at the workplace also showed that they are aware of the context in which they form their judgement.
\end{abstract}

\section{ARTICLE HISTORY}

Received 28 November 2018 Accepted 20 November 2019

\section{KEYWORDS}

Workplace learning; judgement; workplace educators; assessment; inferentialism

\section{Introduction}

Students in vocational education are often required to undergo a form of on-the-job learning as part of their formal education, such as work experience, internship or apprenticeship (Guile and Griffiths 2001). Common characteristics are that students go to a workplace for a prolonged period of time (typically 3 to 6 months fulltime, or one or more days a week for up to a year) and are usually assigned an educator who takes the roles of both supervisor and assessor. When assessment is thus located at the workplace, the workplace educator is given an important role as assessor and their task is essentially judging whether or not a student performs adequately (Van der Vleuten et al. 2010). Assessment at the workplace based on observations of a student performing a specific task, such as making jam or administering IV fluids, is relatively well understood (Gingerich et al. 2014; Govaerts et al. 2011; Kane, Crooks, and Cohen 1999; Kogan et al. 2011; Mazor et al. 2007; Yeates et al. 2013). Assessment of the student's overall performance at the end of a period of workplace learning that requires a postponed judgement of the workplace educator is much less understood. Work placements can vary in length from three months to a year during which time a workplace educator 
witnesses the student's progression. For assessment, this means educators have to oversee a long period of learning and take into account an abundance of information before they can judge a student's performance. However, little is known about how workplace educators reach this judgement and this needs to be better understood in order to gain more insight into the assessment of workplace learning. This paper, therefore, aims at exploring how workplace educators arrive at a judgement about students' professional performance during a prolonged period of time.

\section{Assessment of workplace learning as judgement}

When workplace educators play a pivotal role in establishing whether or not students perform adequately, we need to find a way to describe how they do this. Research from the domain of medical education holds that professional performance at the workplace is complex and its assessment requires human judgement, since it cannot be reduced to the mere application of predefined criteria or the completion of an evaluation form (Berendonk, Stalmeijer, and Schuwirth 2013). Govaerts et al. (2007) suggest conceptualising the assessment of professional performance as a process of judgement and decision-making with educators as active meaning makers at its core. A question that remains is what is meant by 'judgement'.

In research on judgement and decision-making (JDM), judgement is explained as arriving at understanding and research into judgement focuses on how humans make judgements and what potentially influences that process (Goldstein and Hogarth 1997). However, JDM research can be characterised as having a predominantly cognitive approach and it tends to view human judgement separate from the context in which it occurs. By applying a purely JDM perspective to workplace learning, we would not do justice to the complex reality of workplace learning.

The complexity of workplace learning becomes apparent when considering its dual purpose; students acquire the competencies of a specific occupation and also develop corresponding identities (Guile and Griffiths 2001). The development of a professional identity by developing a vocational habitus, which denotes the disposition, values and beliefs that might make a student the right person for the job, can be seen as the hidden curriculum of workplace learning and is often not part of formalised learning outcomes (Colley et al. 2003). Developing a vocational habitus is 'intimately bound up with the social context in which it is situated' (Colley et al. 2003, 475). Furthermore, workplace learning is influenced by social circumstances at the workplace and cannot be considered separate from these circumstances (Virtanen, Tynjälä, and Anneli 2014). We thus propose seeing the workplace as a learning environment that is participatory and where participation by the student is crucial to learning for an occupation (Billett 1994, 2004).

The participatory nature of workplace learning adds an additional layer of complexity to judging student performance: assessors at the workplace are more often than not primarily practitioners with little to no training as educators or assessors (Trede and Smith 2014). These different roles that workplace educators fulfil can have conflicting interests. The student is similar to a new colleague in the sense that both enter the workplace community through legitimate peripheral participation and building relations with co-workers is a natural part of increased participation (Lave and Wenger 1991). As a practitioner, you build a relationship with a student as you would with a new colleague, while simultaneously being responsible for their assessment. This means that workplace educators need to juggle not only the contextual nature of learning at the workplace and the process of identity formation, but also their personal relationship with the student as a colleague and potentially conflicting interests in their different roles.

Seeing the workplace as a participatory learning environment has two important consequences for assessment. First of all, since participation is at the core of workplace learning, assessment is seen as connected to the community of practice at the workplace (Rømer 2002). Furthermore, the aspect of identity development is a crucial part of learning at the workplace and inherently relational, which entails that judging student performance is equally relational (Colley et al. 2003). Workplace educators are part of the community of practice and their judgement of student performance is intricately 
connected to social interactions and relations. Researchers in the domain of JDM have highlighted that the social context of judgement plays an important role (Goldstein and Hogarth 1997; Tetlock 1985). In order to accommodate the participatory nature of workplace learning, we propose adding to the cognitive perspective on judgement by complementing it with a more situated approach through the philosophy of inferentialism, which assumes the ability to reason and make judgements through social interaction as central to understanding (Bakker and Derry 2011). Its emphasis on the social nature of reasoning and judgement creates a promising link between judgement and the participatory character of workplace learning. Thus, we propose seeing assessment of workplace learning as judgement based on social interaction within a community of practice.

Based on the work of Robert Brandom, Bakker and Derry explain inferentialism as a philosophy that 'puts inference at the heart of human knowing' $(2011,6)$. Brandom sees understanding as being able to give reasons or ask for reasons in social interaction and inferences are the conclusions we draw based on the connections between reasons (Guile 2006). These inferential connections between reasons are what enables humans to form judgement. ${ }^{1}$ Judgement here is not isolated, but rather a part of a coherent system of reasons, actions and judgements which Brandom names the web of reasons (Bakker and Derry 2011). Understanding judgement, therefore, involves knowing where a judgement came from and what follows it (Derry 2008). The web of reasons forms a normative context based on the community in which the educator is practitioner, acknowledging the participatory character of the workplace. To reach judgement means to be able to position a momentary judgement against reasons, actions and other judgements in the web of reasons (Guile 2006). Thus, following from an inferentialist perspective we can describe judgement as dependent on social interaction and position it in a web of reasons that connects it to other reasons and actions while simultaneously providing its normative context. In vocational education, research on inferentialism has previously been applied to student learning at the workplace (Bakker, Ben-Zvi, and Makar 2017; Heusdens et al. 2016). We wish to extend this view on judgement by applying it to assessment and shifting the focus form the student to the educator at the workplace.

In sum, by complementing a cognitive view on judgement and decision-making with a participatory approach through the philosophy of inferentialism we propose seeing the assessment of workplace learning as a process of judgement that is inherently social. During this process, educators draw on their web of reasons and make relevant observations and judgements and take actions in order to develop an understanding of students and their performance (Bakker and Derry 2011). In order to learn how workplace educators inform their judgement of a student, this study takes an exploratory approach based on interviews.

\section{Method}

To match the exploratory nature of this study, semi-structured interviews were conducted with workplace educators from different occupational backgrounds. An approach based on interviews was chosen to enable the researcher to access how participants perceive their assessment practice and explore what actions they take to inform their judgement of student performance (Kvale 2007). For analysis purposes template analysis was applied to all transcripts to allow for emerging themes to arise, fitting with an exploratory study (Brooks et al. 2015).

\section{National context}

This study was conducted in Dutch vocational education. The Dutch system of vocational education comprises two levels: senior secondary vocational education and higher professional education. Both levels are primarily aimed at qualifying students for work and include one or multiple prolonged periods of workplace learning. These two levels are considered vocational education for the purpose of this study. Workplace learning is organised by means of on-the-job training that can consist of shorter or longer periods (between 3 and 10 months) where students participate at 
a workplace, and it is considered a fundamental part vocational education (De Bruijn, Billett, and Onstenk 2017). At the workplace, students are assigned an educator, whose main role is that of a practitioner. As educators, they are tasked with mentoring and assessing students.

\section{Participants}

For the purpose of this study, nine workplace educators from three occupational domains and across the two levels of Dutch vocational education were interviewed. Using a convenience sampling method, participants were approached through the network of the research team. Participants were sampled with the help of key informants from different educational institutes. These informants were asked to provide workplace educators they considered to be experienced in their role as assessor (Miles, Huberman, and Saldaña 2014). The participants were approached via email or telephone.

The occupational domains involved were education, engineering (focused on building) and art. These domains were deliberately selected because of their differences when it comes to professional identity and culture. Education is a relatively clearly defined domain when it comes to the type of work professionals do and the competencies that are required for teaching. Engineering is much more diverse when it comes to professional practice and strongly subjected to change (Commissie van Pernis 2011). Art as an occupational domain is the most diverse and the domain where competencies that are difficult to capture, such as creativity and authenticity, play an important role (Rostan 1998). The educational domain comprised the following workplaces: a large regional education and training centre for senior secondary vocational education, a secondary school, and a primary school. From the domain of engineering a large construction company, an individual contractor, and a small architectural firm provided the context for the interviews. In the domain of art, the workplaces were aimed at different art forms: music, film, and illustration and design. All workplaces had several years of experience with educating students, ranging from 5 to 25 years. The resulting variety of workplace educators and insights into different practices have the potential to create a rich picture of how workplace educators reach judgement about students' professional performance. Table 1 represents the sampling across occupational domains and levels of vocational education.

\section{Data collection}

An individual semi-structured interview was conducted with each participant after each had given informed consent. Fitting with the explorative nature of this study, participants were invited in the first phase of the interview to share their experiences with assessing students during workplace learning (Galletta and Cross 2013). During the second phase of the interview, probe questions were used to explore their experiences further and relate these to the theoretical concepts. For this purpose, we developed an interview guide based on theoretical concepts from selected literature (Figure 1). Starting from the premise the workplace is a participatory learning environment, the interviews focused on specific assessment experiences as lived by the educators (Billett 2004; Mazor et al. 2007; Mulder 2014; Wyatt-Smith and Castleton 2005). Literature from the domain of JDM (judgement and decision-making) led to a focus on a non-linear judgement process and the inclusion of the consequences a decision might have on the decision-maker (decision effect)

Table 1. Number of participants per domain and educational level.

\begin{tabular}{llcc}
\hline & EDUCATION & ENGINEERING & ART \\
\hline SECONDARY VOCATIONAL EDUCATION & primary school & $\begin{array}{l}\text { individual contractor } \\
\text { construction company } \\
\text { architectural firm }\end{array}$ & music \\
HIGHER PROFESSIONAL EDUCATION & secondary school & film & illustration \& design \\
regional training centre & 3 & 3 & 3 \\
TOTAL NUMBER OF PARTICIPANTS & & & \\
PER DOMAIN & & & \\
\hline
\end{tabular}




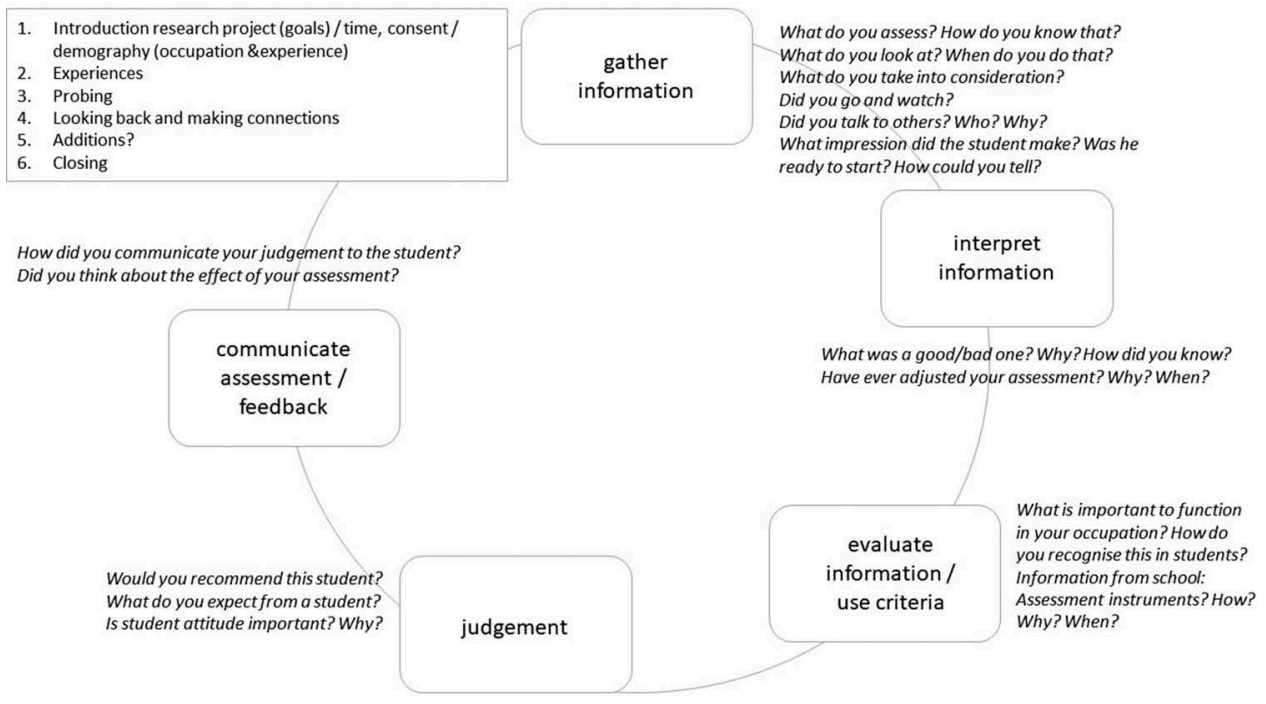

Figure 1. Interview guide.

(Hastie and Dawes 2001; LeBoeuf and Shafir 2005). Further, research into cognitive processes involved in assessment inspired five possible phases of the judgement process: gather information, interpret information, evaluate information, judgement and communication of judgement (Allal 2013; Heller, Sheingold, and Myford 1998; Mazor et al. 2007; Moss, Schutz, and Collins 1998; Schutz and Moss 2004). The interview guide served as a mnemonic for the interviewer and was not intended as a strict guideline. Each interview lasted between 45 and $60 \mathrm{~min}$ and was conducted at the participant's workplace. All interviews were audio-recorded and transcribed verbatim. Any references to organisations or individuals were removed from the transcripts.

\section{Data analysis}

The interviews were conducted and analysed iteratively in order to enable exploration of emerging themes in subsequent interviews. For the analysis, we used template analysis, which allows the researcher to develop a 'hierarchical organization of codes' (a template) from themes identified in the data (King 2004, 258). The template is further developed and refined during subsequent reading and interpreting of the data resulting in a final template that represents the relations between the different themes (King 2004). The present study applied template analysis in phases. The first phase defined three a priori categories for analysis: the judgement process, potentially influencing factors and the content of the judgement. These categories were used to organise the first data set consisting of the transcript of the first four interviews by allocating meaningful segments to the categories. The first data set was then further scrutinised using open coding. The codes generated during this phase were organised into themes and subthemes to form the first version of the template. This initial template was applied to the next three interviews (data set two) and simultaneously the analysis process was used to continue developing the template. Any adjustments made to the template based on the second data set were applied to the first data set as well. Subsequently, the adjusted template was applied to the final two interviews (data set three) to finalise the template and reapplied to the full data set to check for completeness. The themes in the final template were analytically interpreted, leading to the findings as presented here (see Figure 2).

The first group of themes in the template focuses on the judgement process. The findings in the themes gathering information and processing information together illuminate what strategies 


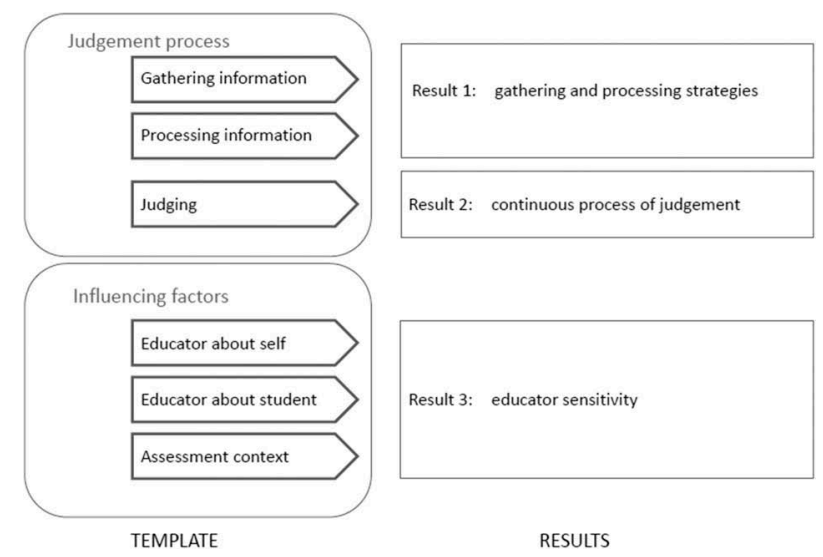

Figure 2. Template in relation to results.

educators employ to inform their judgement. The theme judging resulted in viewing the assessment as a continuous process of judgement. The next group of themes maps contextual factors that potentially influence judgement. Educator about self, educator about student and assessment context converged in educator sensitivity, as these findings showed what educators take into account during the judgement process. The following paragraphs further explore our findings and make relations between themes in the template apparent by discussing the three main results and illustrating these with fragments from the interviews. The participants are referred to by pseudonyms.

\section{Findings}

\section{Gathering and processing strategies}

Interview results show that educators use different strategies when they gather and process the information which informs their judgements. They pick up information about students by simply being present where students work and working alongside them. Chris, an educator for engineering students from higher professional education, describes how he picks up information this way:

Everybody is working and then things stand out, yeah, exactly, it's much more like that. At a certain moment you hear people ask questions and you think, gosh, that's smart, he wouldn't have, two months ago he wouldn't have asked that.

Picking up information enables educators to perceive how students do their work, how they behave and how they relate to co-workers without interfering with their work. When an occupation has specific tasks that can be easily observed, such as cutting a fringe or chairing a meeting, educators also purposefully observe students executing the task to gather information about their performance. Harriet (education, higher professional education) explains how she orchestrates situations to be able to observe students:

Well, if a class has two lessons per week, then I need to find something in my cupboard at least once a week I think. Just to quickly ..., we're often in the same classroom, just to have a look, that is the easiest and I definitely do that at the beginning, just be around or come take a look at the end of a lesson, that is, that will give you a good impression of the atmosphere.

Besides their own perceptions and observations, educators regularly receive information from third parties such as co-workers or customers. Alex, an educator in the arts for higher professional education, puts this clearly when he is asked how he knows what clients think of students: '[B] ecause I ask on both sides how it's going, so both the student and the client'. Matthew (engineering, 
senior secondary vocational education) shares a different approach, where he lets co-workers inform him:

You hear it from the boys around them, you can tell, there's nine of them in a department, and the boys will tell you fairly quickly. Like, hey, this is a good one or this one knows how to get his work done.

Another source of information is the students themselves and educators talk to them to gather data that cannot be observed, such as their motivation or reflection on performance. When asked what type of information Arthur (education, higher professional education) gathers from talking to his student, he reflects: 'Mainly why my student does what she does.' Lisa (education, senior secondary vocational education) indicates that she also gathers a different type of information from conversations with students: 'You get to know somebody, in the sense that I know how to deal with them, so, I should give them compliments for example.' A less essential source of information that educators mention is products students make either for school or work.

While gathering information, educators have to process it in order to reach judgement. As a part of that process, educators discuss their evaluation of a student with others both within and outside the workplace, as Jessica (art, higher professional education) illustrates: 'Well, we often do it together, so, you don't do it alone. You always have a sounding board, because it's unpleasant if I fail somebody while somebody else thinks it's fine.' To process information educators apply criteria which are often very practical and specific. Jessica describes a failing student: 'You're a poor intern when [...] you forget things, or haven't planned things well, or when you don't pick up things.' Besides applying specific criteria, educators also look at the overall picture of the student and their performance. Piecing together this picture requires educators to recognise patterns, which can be based on occupation, school year or the student's general performance level and enable educators to determine how well a student is performing. Arthur explains how he categorises students using patterns based on early impressions: 'Usually after two lesson visits I can say they'll be fine, they'll just about manage or this is going to be difficult. Those are the three categories that often go through my mind.' Similarly, Matthew categorises his students according to job patterns he thinks they are suitable for: 'I tell [them], listen, planning is not for you, I see you more in the area of real estate, but still in construction. Or in housing. In that market, you could function just fine.' Educators also use comparison to other students or colleagues as a method to evaluate a student. Chris describes his current students using this strategy:

We now have two students and they are totally different types. One is a girl and she is much more extrovert ... and the other one is, he has just started this week, but when you look at him, you already know what type of person he is, he is much more modest.

Often experience or intuition enables educators to quickly assess whether a student is suitable and will be successful. Intuition plays a role especially at the beginning of the placement and during the job interview, as Connor (engineering, senior secondary vocational education) illustrates in a similar vein as Chris did in the fragment above: 'When you look at the curriculum vitae, then you practically already know what somebody is worth.' The overall impression of student performance is complete before the assessment instrument is used and educators see the instrument mainly as a tool to translate or justify their decision. Chris explains the role the assessment instrument has for him: 'No, it's, no it's not that is helps me determine the result. It's more that at that moment I express towards [educational institute] how we experienced it. More like that really.'

\section{Continuous process of judgement}

As a second result, the interviews showed that educators engage in a constant process of judgement that starts at the first encounter with a student and ends when the student finishes their on-the-job training. The process begins during the application process, where educators use letters of application, job interviews and sometimes student work as sources of information for the initial judgement 
on suitability for on-the-job training at that specific workplace. When asked at which moment she knows whether or not a student is suitable, Jessica answers: 'Instantly really. When somebody comes in.' Similarly, Matthew indicates that during a job interview, he sometimes reaches the conclusion that the student is not suitable: 'Sometimes guys come in of whom l'd say, look, I don't think that our company is suitable for you.' These examples show how educators make preliminary judgements about students at the start of their placement.

The continuous nature of the judgement process becomes apparent when educators explain the choices they make in guiding students. When guidance strategies or strategies with regards to gathering information are adjusted, these choices are preceded by a judgement about the student's performance. Connor puts it very plainly when he says: 'Someone who can't do very much, I won't give them a difficult job to do.' The jobs he allocates to students are based on his judgement about their competence. Educators do not only adjust how they guide students based on judgements about their performance, they also adjust how they gather information about students. Alex explains: 'And if they're a little shy and self-conscious at the beginning, then you try to get them involved a little more often by looking over their shoulder, and another, well, for another student that just happens by itself.' Similarly, feedback also marks the continuous judgement process. The educator has gathered and processed information, reaches a momentary conclusion about the performance and communicates this to the student by giving feedback. This is also apparent when educators choose to invest in a student whom they think has performed very well. This investment can take the form of a contract or position at the workplace after placement or a financial reward during placement. Jessica explains that this is common practice for her:

We have an intern now, many interns really the past two years, who we often ask to be a production assistant on set, you know, so here you can make some money and will you come work for us, you know.

Connor explains how he takes on a student as an extra pair of hands on Saturdays based on his judgement of the student's character and aptitude: 'I thought he was a nice kid and quick on the uptake and wanted to do all sorts of things, I said, look, I said you can come help me on Saturdays.'

Altogether, these fragments show that from the moment they meet a student, educators make judgements about whether or not the student is suitable and whether they will be successful at the on-the-job training. Essentially the assessment of professional performance in the context of a prolonged period of participation at the workplace is a continuous process of judgement consisting of multiple small judgements that culminate in a final judgement at the end of the placement.

\section{Educator sensitivities}

Fitting with the participatory character of the workplace as a learning environment, the third result reveals contextual factors of which the educators are aware. They are aware of themselves and their own role, they are sensitive to their students' backgrounds and personalities, and they are attentive to the context they work in. The descriptions educators give of themselves show awareness of their identity as an educator. Jessica describes herself as 'I'm pretty strict I think, I expect a lot from interns,' whereas Lisa explains she is 'more the type to say just go ahead and give it a try.' Educators have conceptions of how students learn, both at the workplace and in school, and their own role in the learning process. One of Connor's remarks about how he uses the assessment instrument illustrates this well: 'I use [it] half way as well and then I'm careful not to be too positive, because if you say it's all super half way through, well, then he'll think, the intern thinks he can sit back and relax.' These conceptions are put into practice through educators' expectations of students' learning and attitude. Besides their idea of themselves, educators also know their students. Connor describes a difficult student: 
He was in third year, he did the third year for the second time I think. Yes, that's, then you want to give him a chance at getting a foot in, that he starts enjoying something or that he gets his diploma.

This example shows that Connor knows his student's background and takes that into account. Another aspect is the student's personality and whether it matches the occupation he is training for. Arthur describes a student he struggled with: 'He was pretty hesitant. I had to work very hard in that case and I did find that annoying at times.' Educators mention having a good relationship with students as beneficial to the learning environment and Chris is very honest when he says: 'Well, look, with one student you have a better connection than with another, that's pretty obvious.'

The third contextual factor that educators are sensitive to is the context they work in. They are aware of operating on the intersection of school and work. Since expectations can differ, tension arises between the educational institute and the workplace. This is most tangible when instruments or procedures for workplace learning do not match educators' needs. Jessica describes how little the assessment instrument means to her:

Then I think, well, that does not really apply in our case, or that isn't important, or I didn't see that at all, or that ..., but it's not the case that it helps me with my assessment. One of those forms is purely for the translation. I say, so you want my assessment, these are the important points for you, so then I'll fill it out, but not because it helps me or triggers me.

However, cooperation is considered valuable and educators feel that exchanging information and sharing insights can lead to successful cross-pollination. Alex illustrates this when he explains why meeting his student's teacher is important:

[lt] is valuable because, because you get a feeling for how the teacher knows the student, he knows him from the school situation, and how do l experience that from the workplace. [...] But because the other is there, then you are in contact with both, both school and the workplace [...] and it positions things very clearly, a conversation like that.

Characteristics specific to the workplace also influence expectations of student performance and the day-to-day work a student does, as Chris explains:

Especially when you're a smaller firm, then you have to take into account a couple of other things as well. We can't put students or employees away in a department somewhere and let them do the same thing continuously, so they have to be flexible.

The fragments presented here show what sensitivities educators have regarding contextual factors that are an inherent part of the judgement process. They are aware of their own background and ideas, their students' backgrounds and the complex intersectional context of educating at the workplace.

\section{Conclusion and discussion}

This paper aimed at exploring how workplace educators reach judgement about students' professional performance. The findings from our interview study have demonstrated that educators use multiple strategies to gather and process information, and that they engage in a continuous process of judgement that starts when they first meet the student. Our findings frame this judgement process against a participatory context which includes the educator's self, their social relations with the student and the intersection of the workplace and school. The findings in this study are based on a small number of interviews and can therefore not be seen as representative of all workplace educators. Furthermore, we approached educators who were considered experienced and came recommended by a key person in the relevant educational institute. This might have resulted in participants who take their role as educator particularly seriously and act more conscientiously as assessors. In striving for a variety of participants we aimed at exploring different levels of vocational education and different 
occupational domains, but this is by no means a complete study of these levels or domains, nor can the chosen domains be considered representative for other occupations.

We have taken a participatory approach to the workplace as a learning environment and have emphasised the social and relational character of workplace learning. In line with this approach, our results seem to indicate that educators use information from others to inform their judgement and check it against their peers, which may demonstrate a reliance of the social nature of the workplace. In several areas of assessment literature researchers have made a similar case for assessment as a social and collaborative practice when it comes to complex, open-ended assessment tasks, to enhance the quality of assessment through discussion and sharing experiences (Ecclestone 2001; Moss, Schutz, and Collins 1998). Research referring specifically to educators at the workplace suggests that assessment is a dialogical practice which requires collaboration and shared understanding (Trede et al. 2015; Trede and Smith 2014). During the interviews, educators stressed that collaboration (in any form) is not standard practice, but it happens when timely or simply by serendipity, matching the participatory character of the workplace.

Similar to the collaborative and social aspects of the judgement process, we can also view part of the information processing from a participatory perspective. In line with previous research, our findings indicate that educators seem to successfully use a flexible body of different types of criteria which are adjusted to the situation at hand (Sadler 2009; Wyatt-Smith and Klenowski 2013). This could imply that the criteria used to process information are to an extent situated. As part of this flexible body of criteria, educators use explicit criteria, specified by the educational institute as stated in assessment instruments. However, when participants were asked about how they used these instruments, a common response was that they are a poor match for the reality of the workplace and do little to support the judgement process. The explicit criteria in the instruments poorly represent the complexity of workplace performance: they are either too specific or too general to match the participatory nature of workplace learning. Besides the ill-fitting explicit criteria, educators also use latent criteria, based on personal experience (Wyatt-Smith and Klenowski 2013). Research into the assessment of complex tasks shows that both types of criteria are applied simultaneously and can complement each other (Allal 2013; Mazor et al. 2007; Van der Schaaf, Stokking, and Verloop 2005). Criteria are used to establish whether something is good or bad and in this way represent the norm against which a thing is judged (Sadler 1985). From an inferentialist perspective, as we have taken in this paper, we see that in inferentialism the web of reasons also forms a normative context that enables judgement about whether something is good or bad (Bakker and Derry 2011; Guile 2006). Thus, we could look at the flexible body of criteria from an inferentialist perspective and consider it part of the web of reasons the educator draws upon in order to develop an understanding about the student and their performance.

Besides fitting with an inferentialist perspective, the two types of criteria also invoke a more cognitive parallel. Viewed through the lens of dual-processing theory latent criteria, which play a role when educators form an overall impression of students, match the so-called type 1 processes. The explicit criteria, which are meant to be applied and scored, fit type 2 processes. Dual-processing theory posits that there are two types of cognitive processes involved in judgement: the quick and unconscious type 1 processes, and the slow and conscious type 2 processes (Evans 2008). Both information gathering and processing strategies can be viewed through this lens. Picking up information while working with students, using intuition, pattern recognition, and striving for an overall impression of student performance are examples of type 1 processes. Educators also use type 2 processes such as actively seeking out information about student performance using observation and checking their judgement with peers. The two types of processes, unconscious and conscious, are complementary in both gathering and processing information.

Quick and unconscious processes that inform judgement and situation specific criteria appear to be at odds with traditional views of assessment which require measurable standards of competence and could lead to questioning the quality of an educator's judgement (Trede and Smith 2014). However, the quality of an educator's judgement can be explored by creating an analogy to 
programmatic assessment, which assumes that student performance cannot be judged based on a single assessment, but rather relies on the aggregation of information across a period of time (Schuwirth and van der Vleuten 2011). The literature on programmatic assessment asserts that any single assessment data point is flawed; instead, it requires large samples and long testing times for a trustworthy result (Schuwirth and van der Vleuten 2018; Van der Vleuten et al. 2012). Our findings show that educators use a variety of information sources to inform their judgement and rely on both their own observations and information from others. Considering the duration of an episode of onthe-job-training, educators spend a prolonged period of time interacting with the student, and gathering and processing information while making intermittent judgements throughout. From this perspective, the continuous process of judgement shares characteristics with programmatic assessment. When assessment of workplace learning is seen as a continuous process of judgement, each momentary judgement can be viewed as an assessment data point. Feedback opportunities and adjustments in guidance and information-gathering strategies demonstrate data points where an educator has gathered enough information to reach a momentary judgement. At the end of an episode of on-the-job-training, this results in a large sample of data points that has been gathered over a prolonged period of time. Our findings further also show that educators have a sense of self as assessors and are sensitive to contextual factors. They know their students, spend time with them, and provide them with regular feedback, thus ensuring meaningful assessment. This is in line with the proposition that the validity of complex assessments resides in the users (Van der Vleuten et al. 2012). Assessment of workplace learning and programmatic assessment both require expert judgement because of the similar levels of complexity involved (Berendonk, Stalmeijer, and Schuwirth 2013; Govaerts et al. 2007; Schuwirth and van der Vleuten 2018). This implies that the quality of assessment is inevitably related to the expertise of the educator in both programmatic assessment and the assessment of workplace learning.

Based on insights from the domain of judgement and decision-making (JDM), we expected utility, the effect of a decision, to play a role in the assessment of workplace learning. Utility can be explained as the value you attribute to the result of your decision (Hastie and Dawes 2001). In an assessment context, we find utility when assessors do not fail students because they want to avoid potentially negative consequences such as complaints. In line with research in the domain of medical education, we expected utility to take the shape of a reluctance to fail students or even avoiding it altogether (Cleland et al. 2008; Dudek, Marks, and Regehr 2005). What we found when educators were asked directly if they considered the effect of their judgement is that they mainly considered the pedagogical effect their judgement might have on the student and their learning, and they would strategically use the power of their decision to influence the learning process. The tendency to use judgements for their pedagogical effect positions assessment as crucial to not only learning but also suggests that judgement is closely connected to guidance at the workplace.

As our exploration has shown, assessment of student performance in the workplace may be conceptualised as a continuous process of judgement during which educators employ a variety of strategies. Regarding this process from a participatory perspective, we come to the tentative conclusion that assessment at the workplace using postponed judgement is a highly contextual practice that carries potential for trustworthiness regardless of its inherent complexity. Its potential for trustworthiness could aid the stronger positioning of the workplace in vocational education and training and challenge prevalent concepts of assessment. For further research, it would be interesting to study the judgement process is specific contexts in order to advance understanding of the complex interrelations between assessment of workplace learning and its contexts.

\section{Note}

1. In this study, we use inferences to explore how educators form judgements about students, but this is only part of how inferences play a role in knowing. In Making it Explicit (Brandom 1994) Robert Brandom explains that in communication we understand what the other says by making inferences about their reasons. We then respond 
and are subsequently capable of linking understanding to response and expressing this link. Knowing is then not only inferences one makes, but also entails the capacity to figure out and bridge the differences in individual inferences through communication.

\section{Disclosure statement}

No potential conflict of interest was reported by the authors.

\section{Notes on contributors}

Marlies de Vos is a PhD candidate at the Open University of the Netherlands. She conducts her research at the research group Vocational Education at the Utrecht University of Applied Sciences, where she is also a teacher trainer.

Liesbeth Baartman is an associate professor at Utrecht University of Applied Sciences. She works at the research group Vocational Education. Her main research interests are learning processes in vocational education and assessment practices throughout the curriculum and in relation to the school and work.

Cees van der Vleuten is a professor of Education, chair of the Department of Educational Development and Research, and scientific director of the School of Health Professions Education, Faculty of Health, Medicine and Life Sciences, Maastricht University, the Netherlands.

Elly de Bruijn is a professor at both Utrecht University of Applied Sciences and the Open University of the Netherlands. She is head of the research centre for Learning and Innovation in Utrecht. Her main research interests focus on learning processes in vocational education and the guidance by vocational educators.

\section{ORCID}

M. E. De Vos (iD http://orcid.org/0000-0002-3029-5562

C. P. M. Van Der Vleuten (iD http://orcid.org/0000-0001-6802-3119

E. De Bruijn (iD http://orcid.org/0000-0003-4391-4681

\section{References}

Allal, L. 2013. "Teachers' Professional Judgement in Assessment: A Cognitive Act and A Socially Situated Practice." Assessment in Education: Principles, Policy and Practice 20 (1): 20-34. doi:10.1080/0969594X.2012.736364.

Bakker, A., and J. Derry. 2011. Lessons from Inferentialism for Statistics Education. Mathematical Thinking and Learning13 (1-2): 5-26. doi:10.1080/10986065.2011.538293

Bakker, A., D. Ben-Zvi, and K. Makar. 2017. "An Inferentialist Perspective on the Coordination of Actions and Reasons Involved in Making a Statistical Inference." Mathematics Education Research Journal 29: 455-470. doi:10.1007/s13394016-0187-x.

Bakker, A., and J. Derry. 2011. "Lessons from Inferentialism for Statistics Education." Mathematical Thinking and Learning 13 (1-2): 5-26. doi:10.1080/10986065.2011.538293.

Berendonk, C., R. Stalmeijer, and L. W. T. Schuwirth. 2013. “Expertise in Performance Assessment: Assessors' Perspectives." Advances in Health Sciences Education 18 (4): 559-571. doi:10.1007/s10459-012-9392-x.

Billett, S. 1994. "Situating Learning in the Workplace - Having Another Look at Apprenticeships." Industrial and Commercial Training 26 (11): 9-16. doi:10.1108/00197859410073745.

Billett, S. 2004. "Workplace Participatory Practices: Conceptualising Workplaces as Learning Environments." Journal of Workplace Learning 16 (6): 312-324. doi:10.1108/13665620410550295.

Brandom, R. 1994. Making It Explicit. Cambridge, MA: Harvard University Press.

Brooks, J., S. McCluskey, E. Turley, and N. King. 2015. "The Utility of Template Analysis in Qualitative Psychology Research." Qualitative Research in Psychology 12 (2): 202-222. doi:10.1080/14780887.2014.955224.

Cleland, J. A., L. V. Knight, C. E. Rees, S. Tracey, and C. M. Bond. 2008. "Is It Me or Is It Them? Factors That Influence the Passing of Underperforming Students." Medical Education 42 (8): 800-809. doi:10.1111/j.1365-2923.2008.03113.x.

Colley, H., D. James, K. Diment, and M. Tedder. 2003. "Learning as Becoming in Vocational Education and Training: Class, Gender and the Role of Vocational Habitus." Journal of Vocational Education and Training 55 (4): 471-498. doi:10.1080/13636820300200240.

Commissie van Pernis. 2011. "HBO Techniek in BEDRIJF." Vereniging Hogescholen, https://www.vereniginghogescho len.nl/kennisbank/techniek/artikelen/hbo-techniek-in-bedrijf. December 2011. 
De Bruijn, E., S. Billett, and J. Onstenk. 2017. "Vocational Education in the Netherlands." In Enhancing Teaching and Learning in the Dutch Vocational Education System: Reforms Enacted, edited by E. de Bruijn, S. Billett, and J. Onstenk, 1-34. Switzerland: Springer International Publishing.

Derry, J. 2008. "Abstract Rationality in Education: From Vygotsky to Brandom." Studies in Philosophy Education 27: $49-62$. doi:10.1007/s11217-007-9047-1.

Dudek, N. L., M. B. Marks, and G. Regehr. 2005. "Failure to Fail: The Perspectives of Clinical Supervisors." Academic Medicine 80 (10 Supplement): S84-87. doi:10.1097/00001888-200510001-00023.

Ecclestone, K. 2001. "II Know a 2:1 When I See It': Understanding Criteria for Degree Classifications in Franchised University Programmes." Journal of Further and Higher Education 25 (3): 301-313. doi:10.1080/03098770126527.

Evans, J. St. B. T., 2008. "Dual-Processing Accounts of Reasoning, Judgment, and Social cognition." Annual Review of Psychology 59 (1): 255-278. doi:10.1146/annurev.psych.59.103006.093629.

Galletta, A., and W. E. Cross. 2013. Mastering the Semi-Structured Interview and Beyond: From Research Design to Analysis and Publication. New York: NYU Press.

Gingerich, A., C. P. M. van der Vleuten, K. W. Eva, and G. Regehr. 2014. "More Consensus than Idiosyncrasy: Categorizing Social Judgments to Examine Variability in Mini-CEX Ratings." Academic Medicine : Journal of the Association of American Medical Colleges 89 (11): 1510-1519. doi:10.1097/ACM.0000000000000486.

Goldstein, W. M., and R. M. Hogarth, Eds.. 1997. Research on Judgment and Decision Making: Current, Connections and Controversies. Cambridge: Cambridge University Press.

Govaerts, M. J. B., C. P. M., van der Vleuten, L. W. T. Schuwirth, and A. M. M. Muijtjens. 2007. "Broadening Perspectives on Clinical Performance Assessment: Rethinking the Nature of In-training Assessment." Advances in Health Sciences Education 12 (2): 239-260. doi:10.1007/s10459-006-9043-1.

Govaerts, M. J. B., L. W. T.Schuwirth, C. P. M.van der Vleuten, and A. M. M. Muijtjens. 2011. "Workplace-based Assessment: Effects of Rater Expertise." Advances in Health Sciences Education 16 (2): 151-165. doi:10.1007/s10459010-9250-7.

Guile, D. 2006. "Learning Across Contexts." Educational Philosophy and Theory 38 (3): 251-268. doi:10.1111/j.14695812.2006.00193.x.

Guile, D., and T. Griffiths. 2001. "Learning Through Work Experience." Journal of Education and Work 14 (1): $113-131$. doi:10.1080/13639080020028738.

Hastie, R., and R. M. Dawes. 2001. Rational Choice in an Uncertain World: The Psychology of Judgement and Decision Making. Thousand Oaks: Sage Publications.

Heller, J. I., K. Sheingold, and C. M. Myford. 1998. "Reasoning about Evidence in Portfolios: Cognitive Foundations for Valid and Reliable Assessment." Educational Assessment 5 (1): 5-40. doi:10.1207/s15326977ea0501.

Heusdens, W. T., A. Bakker, L. K. J. Baartman, and E. de Bruijn. 2016. "Contextualising Vocational Knowledge: A Theoretical Framework and Illustrations from Culinary Education." Vocations and Learning 9 (2): $151-176$. doi:10.1007/s12186-015-9145-0.

Kane, M., T. Crooks, and A. Cohen. 1999. "Validating Measures of Performance." Educational Measurement: Issues and Practice 18 (2): 5-17. doi:10.1111/j.1745-3992.1999.tb00010.x.

King, N. 2004. "Essential Guide to Qualitative Methods in Organisational Research." In Using Templates in the Thematic Analysis of Text, edited by C. Cassel and G. Symon, 256-270. London: Sage Publications .

Kogan, J. R., L. Conforti, E. Bernabeo, W. lobst, and E. Holmboe. 2011. “Opening the Black Box of Clinical Skills Assessment via Observation: A Conceptual Model.” Medical Education 45 (10): 1048-1060. doi:10.1111/j.1365-2923.2011.04025.x.

Kvale, S. 2007. Doing Interviews. London: Sage Publications .

Lave, J., and E. Wenger. 1991. Situated Learning: Legitimate Peripheral Participation. Cambridge: Cambridge University Press.

LeBoeuf, R. A., and E. B. Shafir. 2005. "Decision Making." In The Cambridge Handbook of Thinking and Reasoning, edited by K. J. Holyoak and R. G. Morrison, 243-265. New York: Cambridge University Press.

Mazor, K. M., M. L. Zanetti, E. J. Alper, S. V. David Hatem, V. M. Barrett, W. Gammon, and M. P. Pugnaire. 2007. "Assessing Professionalism in the Context of an Objective Structured Clinical Examination: An In-depth Study of the Rating Process." Medical Education 41 (4): 331-340. doi:10.1111/j.1365-2929.2006.02692.x.

Miles, M. B., A. M. Huberman, and J. Saldaña. 2014. "Qualitative Data Analysis: A Methods Sourcebook." In Third Edit. Thousand Oaks: Sage Publications. 381.

Moss, P. A., A. M. Schutz, and K. M. Collins. 1998. "An Integrative Approach to Portfolio Evaluation for Teacher Licensure." Journal of Personnel Evaluation in Education 12 (2): 139-161. doi:10.1023/A:1008081027322.

Mulder, M. 2014. "Conceptions of Professional Competence." In International Handbook of Research in Professional and Practice-based Learning, edited by S. Billett, C. Harteis, and H. Gruber, 107-137. Dordrecht: Springer.

Rømer, T. A. 2002. "Situated Learning and Assessment." Assessment and Evaluation in Higher Education 27 (3): $233-241$. doi:10.1080/0260293022013859.

Rostan, S. M. 1998. "A Study of the Development of Young Artists: The Emergence of on Artistic and Creative Identity." Journal of Creative Behaviour 32 (4): 278-301. doi:10.1002/j.2162-6057.1998.tb00822.x.

Sadler, D. R. 1985. "The Origins and Functions of Evaluative Criteria." Educational Theory 35 (3): 285-297. doi:10.1111/ edth.1985.35.issue-3. 
Sadler, D. R. 2009. "Indeterminacy in the Use of Preset Criteria for Assessment and Grading." Assessment and Evaluation in Higher Education 34 (2): 159-179. doi:10.1080/02602930801956059.

Schutz, A. M., and P. A. Moss. 2004. "Reasonable Decisions in Portfolio Assessment : Evaluating Complex Evidence of Teaching." Education Policy Analysis Archives 12 (33): n33. doi:10.14507/epaa.v12n33.2004.

Schuwirth, L. W. T., and C. P. M. van der Vleuten. 2011. "Programmatic Assessment: From Assessment of Learning to Assessment for Learning." Medical Teacher 33 (6): 478-485. doi:10.3109/0142159X.2011.565828.

Schuwirth, L. W. T., and C. P. M. van der Vleuten. 2018. "How 'testing' Has Become 'programmatic Assessment for Learning'." Health Professions Education (Advanced online publication). doi:10.1016/J.HPE.2018.06.005.

Tetlock, P. E. 1985. "Accountability: The Neglected Social Context of Judgment." Research in Organizational Behavior 7 (1): 297-332.

Trede, F., M. Mischo-Kelling, E. M. Gasser, and S. Pulcini. 2015. "Assessment Experiences in the Workplace: A Comparative Study between Clinical Educators' and Their Students' Perceptions." Assessment \& Evaluation in Higher Education 40 (7): 1002-1016. doi:10.1080/02602938.2014.960363.

Trede, F., and M. Smith. 2014. "Workplace Educators' Interpretations of Their Assessment Practices: A View through A Critical Practice Lens." Assessment \& Evaluation in Higher Education 39 (2): 154-167. doi:doi.10.1080/ 02602938.2013 .803026$.

Van der Schaaf, M. F., K. M. Stokking, and N. Verloop. 2005. “Cognitive Representations in Raters' Assessment of Teacher Portfolios." Studies in Educational Evaluation 31 (1): 27-55. doi:10.1016/j.stueduc.2005.02.005.

Van der Vleuten, C. P. M., L. W. T. Schuwirth, E. W. Driessen, J. Dijkstra, D. Tigelaar, L. K. J. Baartman, and V. T. Jan. 2012. "A Model for Programmatic Assessment Fit for Purpose." Medical Teacher 34 (3): 205-214. doi:10.3109/ $0142159 X .2012 .652239$.

Van der Vleuten, C. P. M., W. T. Lambert, F. S. Schuwirth, E. W. Driessen, and B. Hodges. 2010. "The Assessment of Professional Competence: Building Blocks for Theory Development." Best Practice \& Research Clinical Obstetrics \& Gynaecology 24 (6): 703-719. doi:doi.10.1016/j.bpobgyn.2010.04.001.

Virtanen, A., P. Tynjälä, and E. Anneli. 2014. "Factors Promoting Vocational Students' Learning at Work: Study on Student Experiences." Journal of Education and Work 27 (1): 43-70. doi:doi.10.1080/13639080.2012.718748.

Wyatt-Smith, C., and G. Castleton. 2005. "Examining How Teachers Judge Student Writing: An Australian Case Study." Journal of Curriculum Studies 37 (2): 131-154. doi:doi.10.1080/0022027032000242887.

Wyatt-Smith, C., and V. Klenowski. 2013. "Explicit, Latent and Meta-Criteria: Types of Criteria at Play in Professional Judgement Practice." Assessment in Education: Principles, Policy and Practice 20 (1): 35-52. doi:doi.10.1080/ 0969594X.2012.725030.

Yeates, P., P. O'Neill, K. Mann, and K. Eva. 2013. "Seeing the Same Thing Differently: Mechanisms that Contribute to Assessor Differences in Directly-observed Performance Assessments." Advances in Health Sciences Education 18 (3): 325-341. doi:doi.10.1007/s10459-012-9372-1. 